\title{
The feedstock curve: novel fuel resources, environmental conservation, the force of economics and the renewed east-west power struggle
}

\author{
Oliver R. Inderwildi • Fabian Siegrist • \\ Robert Duane Dickson • Andrew J. Hagan
}

Received: 1 April 2014/ Accepted: 30 April 2014/Published online: 22 May 2014

(C) The Author(s) 2014. This article is published with open access at Springerlink.com

\begin{abstract}
Rapid technological advancements can make previously uneconomic resources and/or feedstock available within significantly reduced timeframes. This can and will further transform the global energy landscape and moreover, will impact the mix of feedstock we use for energy provision and material production-the so-called Feedstock Curve. Herein, three current examples are assessed to illustrate that this restructuring has by far wider reaching implications: Firstly, we examine how unconventional resources-mainly produced using fractured cracking techniques-have restructured the US energy landscape, are now fueling the US economic recovery and will impact the geopolitical balance. Secondly, we assess how unconventional resources could impact European energy security, the Crimean crisis and redirect global cash flows. Thirdly, we analyse the potential impact of so-called methane hydrates deposited off the shores of Japan on the energy transition of the Island nation and how they might impact its trade deficit and long-term economic outlook. Last but not least, we will present arguments that unconventional resources, when regulated properly, may be a blessing for the environment. With these examples, this
\end{abstract}

The contribution reflects the views of the author, not the institution.

O. R. Inderwildi ( $\square)$

Smith School, University of Oxford, South Parks Road, Oxford OX1 3QY, UK

e-mail: oliver.inderwildi@smithschool.ox.ac.uk

F. Siegrist $\cdot$ R. D. Dickson

Deloitte LLP, 30 Rockefeller Plaza, New York City, NY

10111, USA

A. J. Hagan

World Economic Forum, 91-93 route de la Capite,

1223 Cologny, Geneva, Switzerland think piece and concept note will illustrate the interconnectedness of economics, politics, environmental conservation and technology.

Keywords Energy security - Foreign policy · International security · Resources · Global change

\section{Introduction}

Not long ago, anyone who had mentioned that the United States would likely become energy independent or would have said that they could consider exporting fossil resources would have received roaring laughter. The energy market in North America has, however, undergone a full transformation and neither energy independence nor the US as a fuel exporting country is an unrealistic assumption [1]. Novel feedstock such as shale gas and tight oil are impacting the resource mix or as we coin it-the Feedstock Curve. Why Feedstock Curve? Because these novel fossil resources do not only impact the energy sector but also the petrochemical industries as they are their critical feedstock.

Main fossil fuel resources used to date were so-called conventional resources, meanwhile substantial amounts of unconventional resources are adding to the feedstock curve. For a detailed discussion of resources grades, we refer to a previous publication [2]. Conventional reserves are the most accessible and least technically challenging to bring into production; they require relatively little capital and energy investments for production and hence are the most profitable resources. Most of the remaining conventional oil and gas reserves are located in Russia and the Middle East. In contrast, unconventional reserves are not readily recovered because they are deposited within rock formations, such as shale gas and tight oil, or are combined with sand as in case of 
oil sands. Technology such as fractured cracking (fracking) of rock formations or extraction of oil from oil sands is required to produce the resource; however, the technology requires significant upfront investments while production requires significant supplementary energy [3]. Consequently, unconventionals have a considerably higher production cost, deliver less net energy [4] and cause more greenhouse gas emissions. Yet, significant amounts of these resources are located in the Western World!

One of the authors has previously reported on the decline of conventional reserves; unconventional reserves are likely to mitigate shortcomings in conventional production but are only economic at sustained, high resource prices. Especially in North America, this novel feedstock has had and will remain to have a significant impact on macroeconomics, trade balances and energy security and, consequently, the North American economic outlook as well as competitiveness. We hereafter analyse illustrative cases in order to draw a picture of the potential impact of conventional resources.

\section{Analysis}

North America and the energy transformation

In order to illustrate the importance of unconventional resources for supply security, we will hereafter assess the impact and the prospects for the United States, the country most impacted by the transition of the Feedstock Curve. We base our assessment on estimates of the US Government's Energy Information Administration (EIA) [5], the Organisation for Economic Cooperation and Development (OECD) as well as the Census Bureau [6].

Unconventional Gas: For decades the United States was dependent on imports of natural gas, historically in gaseous form and more recently, approximately since 1985, also in form of liquefied natural gas (LNG). While diversified supply of natural gas and oil from abroad ensured US energy security, it obviously came with cash transfers abroad and consequently detrimentally affected the trade balance [7]. At the height of import dependence, the United States imported well over four trillion cubic feet (tcf); however, imports have dropped below $3 \mathrm{tcf}$, while domestic production of natural gas has risen to more than 8 tcf [8] per annum. The enabler of this shift in supply is a combination of technological advancements such as horizontal drilling, fractured cracking of shale rock and advanced chemicals that allow cracking of shale under relatively benign conditions [9]. This enabler had the mentioned transformative impact of the American feedstock curve and is likely to continue to have a significant impact. Figure 1 depicts estimates by the EIA that conclude that domestic gas production will continue to rise-albeit at

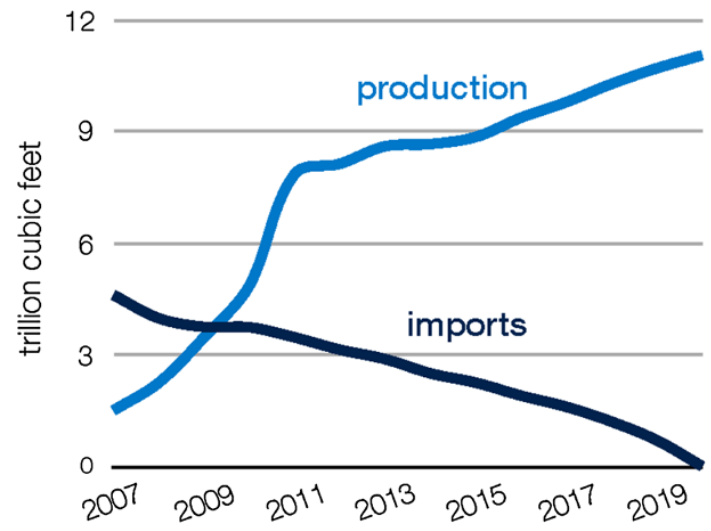

Fig. 1 US production and imports of natural gas in tcf; data taken from EIA (footnote)

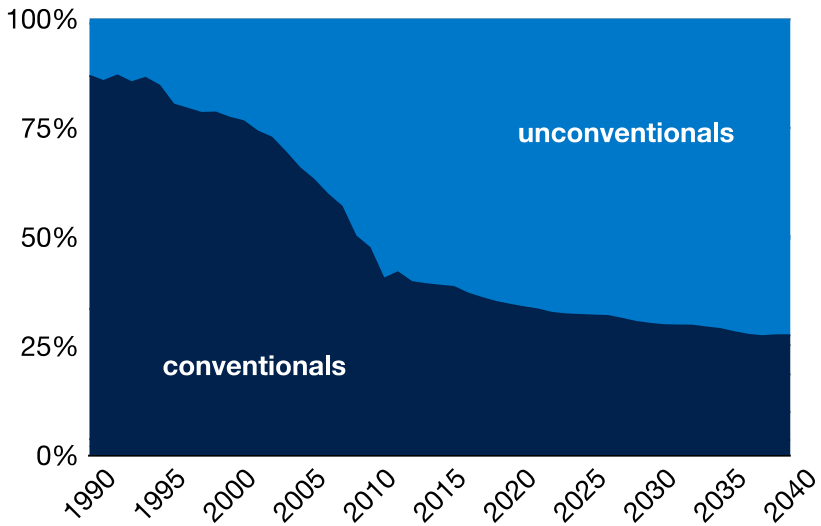

Fig. 2 Forecasted natural gas consumption by type (conventional vs. unconventional); data from the EIA [11]

a slower rate-and imports will reduce to negligible amounts before 2020. This assumptions is supported by the fact that in the US degasification terminals for LNG are being refitted to be liquefaction units as the shale gas boom is continuing to affect the feedstock so drastically that surplus of gas rather than shortages are expected. For instance, Cheniere Energy decided to entirely alter the purpose of their LNG terminals and refit them to liquefaction rather than regasification units [10], a decision well supported by data displayed in Fig. 1.

What has spurred this drastic restructuring of the US situation? Technological advancements, for instance fracking and horizontal drilling, allow unconventional gas reserves to be released from soft rock such as shale and sandstone, vide supra. Already today, more than $50 \%$ of the US' natural gas production stem from unconventional wells, such as shale and tight gas wells, by 2040 more than $75 \%$ will come from unconventionals [11]. Figure 2 illustrates how unconventional (domestic) gas forces conventional (imported) gas out of the feedstock curve.

The increased shale gas production has a beneficial effect as it is expected that the long-term volume of natural 


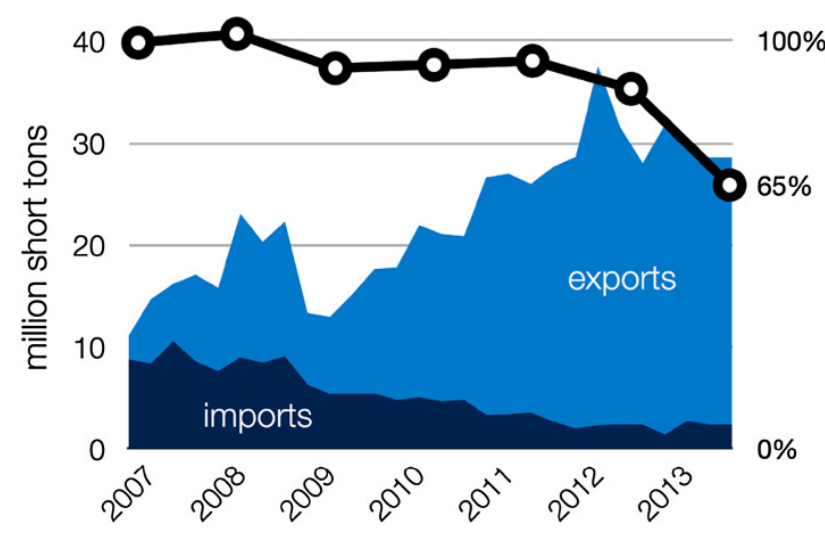

Fig. 3 US coal production, imports and exports

gas liquids (NGLs). These are the more important feedstock for the (petro-)chemical industry [12] as they have many values beyond their ability to produce heat, i.e. the calorific value and are hence very valuable for the chemical industries [13]. The production of NGLs is, however, uncertain as it will vary considerably with the so-called wetness of the natural gas produced. In 2013, Troner estimated that NGL production could amount to $1.5-1.8$ million barrels per day (mbd) [14].

While this is excellent news for the recovery of the American economy, many claim that it is bad news for the environment as production of unconventional reserves has significant environmental externalities as it can impact water supply as well as purity (1) [15] and is likely to be more emission intense than conventional natural gas (2) [16]. While both issues are valid concerns when utilising these resources, they are not insurmountable: Firstly, water impact can be mitigated by technological improvement which can be driven by regulation and hence, this should be relatively straightforward to solve. Secondly, while more emission intense, unconventionals can crowd out coal which will lead to an overall reduction of greenhouse-gas emissions. An approximation by the International Energy Agency (IEA) suggests that the greenhouse-gas emissions caused by unconventional gas are half those of coal (calculated in $\mathrm{gCO}_{2(\mathrm{eq})} / \mathrm{kWh}$ ) [17]. Consequently, overall emissions are likely to be reduced significantly if unconventional gas crowds out coal. Indeed, the EIA assessed a sustained decline in US greenhouse gas emission since 2010 while the national economy is growing at several \% annually [18].

But is this happening? Is the reduction really due to a crowding out of coal? In order to assess whether is crowding out is indeed happening, we look at the imports and exports of coal from and to the US as well as domestic coal production after 2007, when the shale gas boom really took off (Fig. 3). From this graph it can be seen that coal imports have fallen to negligible levels from 2007 onwards, while exports have almost tripled during the same period. Overall production on the other hand declined by onethird! Figure 3 depicts the exports and imports of coal to/ from the United States as well as domestic production.

From this graph it can be clearly seen that coal is leaving the feedstock curve in the US, most likely crowded out by cheap shale gas. A global shale gas boom could therefore indeed lead to a crowding out of most pollution energy sources such as coal. However, utilising these resources will not be as straightforward in other regions of the world owing to differences in legal frameworks (see below) and geological circumstances (see "Shale gas and the rest of the world").

Due to different property rights, utilising shale gas will be much more challenging in other parts of the world, e.g. the European Union. For instance, in the United States resources beneath your land are considered your property which gives a private or legal person a clear incentive to produce these or sell the rights for production [19]. In the EU, resources are a common good and hence belong to the government which leads to a clear incentive to oppose techniques such as fracking below your property as they could pose a risk for both real estate and value of premises. However, the IEA estimates that the EU has more than 600 tcf of unconventional gas reserves, which could act as a terrific back-up fuel to balance out intermittency of renewables and/or assisting the transition away from nuclear power. However, analogue to the negative public perception of nuclear power, unconventional resources encounter scepticism from the environmentally conscious European public. Recent happenings in Eastern Europe, however, could drastically alter public perception, see "Europe, the Loss of Resources, and the Renewed Power Struggle".

Unconventional Oil: Even more important for the US economy is - of course-the most precious fossil fuel resource, oil. American oil production has peaked in the 1960s [20] and endeavours to increase energy security using bio-based or synthetic fuels have essentially failed [21, 22].

In case of oil, the "unconventional revolution" transformation has not yet taken place, but it is likely that socalled tight oil will play a crucial role in the continued transformation of the feedstock curve. Tight oil is-analogue to shale gas-conventional oil that is trapped in soft stone formations and can be produced using fracking techniques. Also here, technology transformed uneconomical and inaccessible resources into viable feedstock within years. Tight oil is pushing current US oil production past $10 \mathrm{mbd}$ reducing the need for imports from $60 \%$ in 2005 to $40 \%$ in 2012 (Fig. 4). Forecasts by the EIA assume that by 2016 the need for imports will be reduced to $25 \%$. Especially with crude oil prices sustained over $\$ 100$ [23], this will have very positive effects on the US trade 


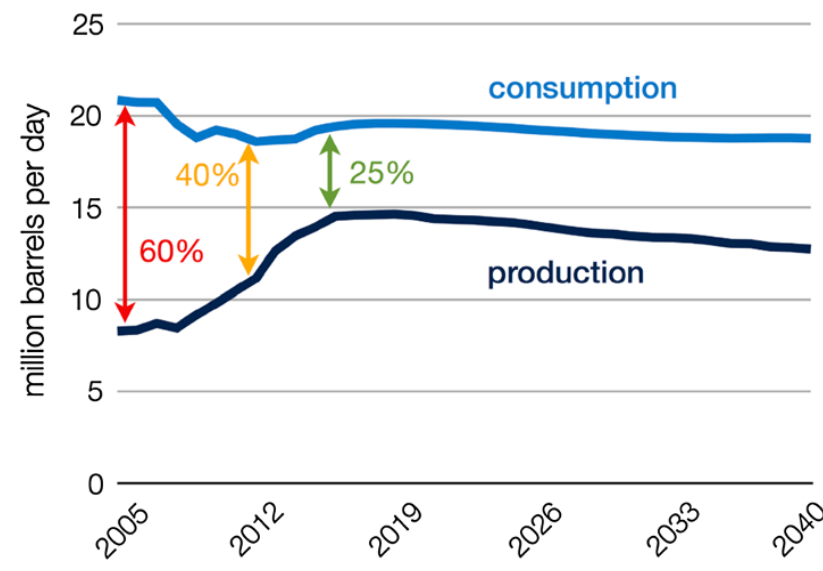

Fig. 4 US oil production and consumption, a gap that widened over decades is now narrowing again

balance and hence economic outlook, vide infra. Moreover, this has wide ranging political implications as most of these imports could come from neighbouring Canada and Mexico both friendly to the US and dependent on revenues from resource exports [24]. At present US military presence not only provides stability to the Middle East but US forces are also key in policing critical trade routes. Will the need for this presence and the associated cost persist or will the US reconsider? This issue will be considered in a later section of this think piece.

Resource imports, trade balances and macroeconomics

For more than a decade, the US has borrowed money, mainly from China, in order to transfer it to resourceexporting states to satisfy its domestic resource hunger. A significant proportion of this resource demand is due to a notoriously inefficient car fleet. Will this affect the longterm economic outlook?

There is no short answer to this very important question, nor is there one correct answer. Many academics and policymakers have expressed grave concerns about the widening US trade deficit and the consequently increasing foreign debt, however, there is a lot of disagreement about the severity of the problem and the potential consequences [25]. The United States have had trade deficits for most years in the last 3 decades, which led to negative balance of payments and subsequently to a very significant foreign debt. This works as long as there are sufficient foreign investors (mainly governments) that lend the US money, but should these sources run dry, the US might pay dearly [26]. Credit ratings of the US Government have already been reduced by most rating agencies, initially by Standard \& Poor's in late 2011 [27]. A heavy debt burden can hamper economic growth as governments have less financial resources for stimulating innovation and economic growth [28]. Hence, the foreign debt of the US creates risk and uncertainty for its long-term economic outlook as it's likely to hamper or redirect foreign direct investments. However, the Council on Diplomatic Relations estimates that recently roughly $50 \%$ of the US trade deficit was due to just oil [29]. The narrowing of the differential between consumption and production of oil as well as gas, vide supra, will hence reduce the trade deficit, ease balance of payment issues and consequently will affect foreign debt and credit rating of the United States [30]. All this will thus free up resources to stimulate the American economy and hence, technological advancements in unconventional resource production not only transformed the feedstock curve and hence the energy landscape, but are also likely to fuel US economic recovery. One of the authors has previously outlined that advanced economies are indeed able to translate resource wealth into economic growth and innovation without suffering from the so-called resources or carbon curse [31]. The US were already able to become the worldwide leading economy based on conventional resource wealth post WWII and are likely to transform this newly gained, unconventional resource wealth in a similar manner. Innovation in fuel production has therefore clearly had an impact on the energy landscape, domestic greenhouse-gas emissions and the long-term economic outlook. Will this success be transferable to other areas of the world and what are the political consequences of this transition? These issues will be explored in the second part of this think piece.

Shale gas and the rest of the world

Unconventional fossil fuel reserves are not an American phenomenon, many regions of the world have significant reserves of shale gas and tight oil [32]. Figure 5 gives an overview over shale gas reserves as an example of abundant unconventionals: In South America reserves are mainly located in Argentina and Brazil, the two largest countries on this continent, while in North America the reserves are spread out fairly evenly over Mexico, the US and Canada. In Asia, shale gas reserves are centered in China and in Australia within Australasia.

The Chinese shale gas reserves are significant, approximately twice the size the reserves the US have at hand [33]. Since energy security is very high on the Chinese political agenda and air pollution could be reduced by replacing coal with clean-burning natural gas, utilization of unconventional gas is a no-brainer for China. However, the Chinese resources have proven to be more difficult to produce than US reserves which has delayed production. Ultimately, however, China will tap into these resources as energy security and economic concerns will be major driving forces; for these reasons China even acquired 


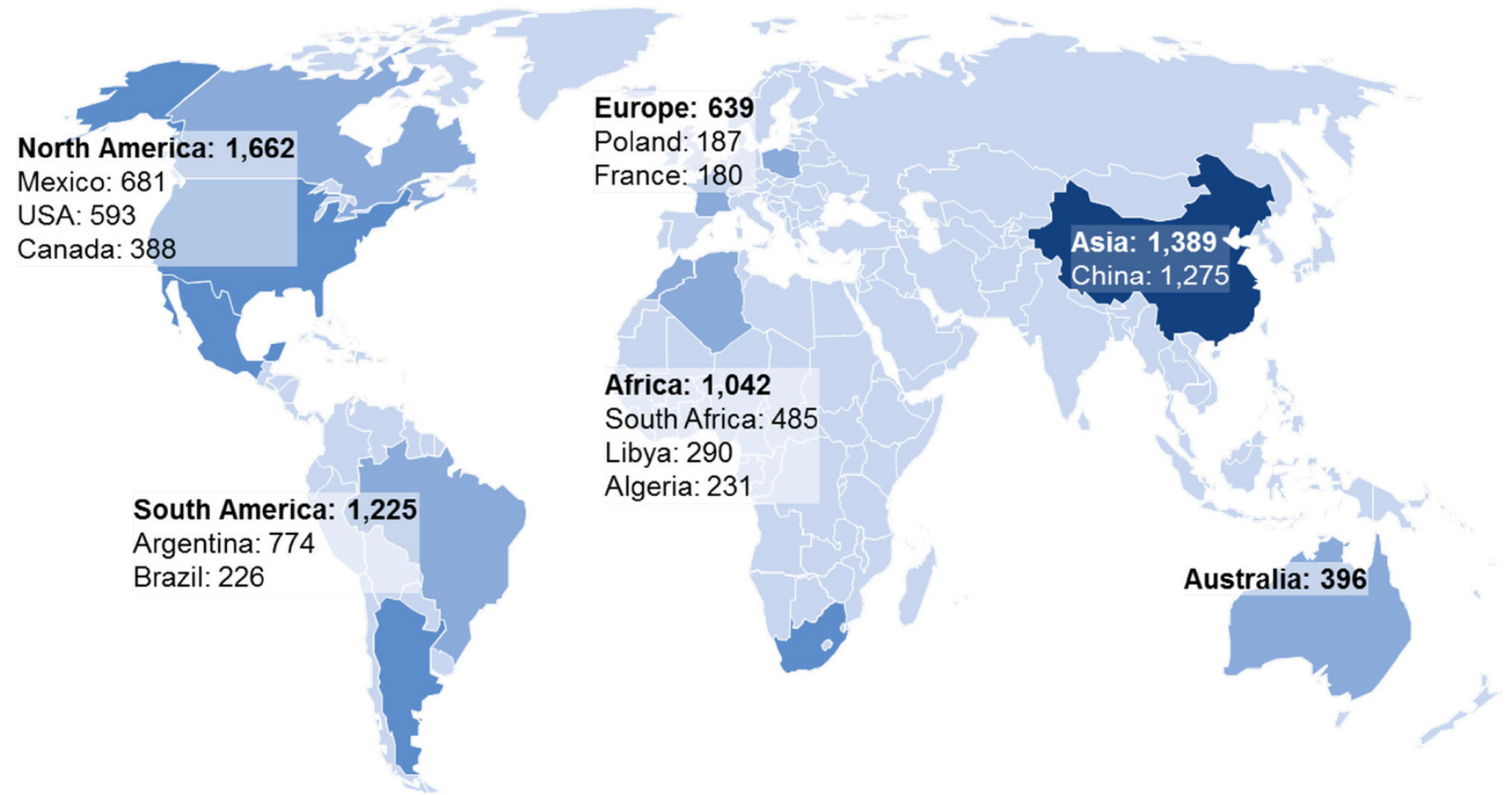

Fig. 5 Estimation of technically recoverable global shale gas resources (in tcf) Source: US EIA, World Shale Gas [38]

companies with specific know-how in shale gas production [34].

Also Europe has shale-gas reserves albeit significantly smaller than the larger continents, and at the same time the countries with the greatest endowments, France and Poland, are both reluctant to produce-in fact France has even banned exploration of shale gas [35]. A critical obstacle preventing deployment on shale gas in Europe is public perception of the environmental risks posed by unconventionals production. However, many European countries have stringent targets for decarbonisation and, analogue to the US, gas can crowd out coal thereby reducing carbon emissions [36]. Moreover, European shale gas causes fewer emissions than natural gas from outside the EU, imported via LNG terminals or pipelines, mainly because of emissions from liquefaction and regasification or long-distance gas transport [37]. These are two very strong arguments for shale gas utilization, another strong argument is to come! A drawback of shale gas is that the potentially cheap source of energy, might pose a threat to the significant investments renewable energy requires (crowding out). On the other hand natural gas, due to its flexibility, can supplement the transformation of the energy landscape. Gas-fired power plants are very flexible as they can easily be powered up and down and could therefore provide a suitable backup needed to cope with intermittent power supply from solar and wind sources. It will be important to smartly incentivize the energy transition in order to balance renewables and gas to gain maximum benefits for both the climate and the economy.

Europe, the loss of resources, and the renewed power struggle

The current situation in the Ukraine and the consequently rising tension between the east and west could, however, draw public attention away from environmental issues towards energy security concerns. At the moment, Europe (especially Germany) is dependent on Russian gas: roughly a third of the gas used in the OECD Europe is imported from Russia [39] approximately the amount Norway, the biggest domestic producer, provides. The de facto annexation of the Crimean by the Russian Federation will deplete the resource base Western Europe has easy access to, detrimentally affecting its already weak energy security and hence the Crimean question can be seen as the biggest security crisis Europe had to face since the end of the Cold War. The incorporation of the territory adjoining the Black Sea into the Russian Federation will annex the rights to resources located offshore in the Black Sea [40] and hence these resources are moved into Russian dominated territory, away from the EU. There are two straightforward solutions to the crisis: increasing domestic production of natural gas or diversifying imports [41]. During the first Ukrainian gas crisis in 2009, the EU has taken important steps and increased the number of interconnectors for both electricity and natural gas in order to increase its energy 
security and mitigate reliance on volatile regions in Eastern Europe. However, in the meantime Nord Stream has gone online [42] (in 2012 to be precise) and this has on the one hand circumvented politically volatile regions but on the other hand increased dependence on Russian gas! As always, energy security is based on diversified supply of different energy resources, however, this dogma is unlikely to hold right now in Europe. Therefore, the EU has expanded the capacity for gas storage and LNG regasification since 2005; for instance, the regasification capacity will raise almost four times between 2005 and 2015 from 2.5 tcf to 9.2 tcf per annum. This additional capacity will reduce reliance on Russian gas if sufficient LNG, for instance from the US, is on the market. Very recently, the speaker of the US House, John Boehmer, stated that expediting the approval to export natural gas to the EU in order to mitigate the Union's reliance on Russian gas was one way to stand up to geopolitical aggression [43]. In such a scenario, natural gas would be used as a strategic weapon - a geopolitical weapon. Were this to happen and effective, unconventionals and their production technology would have directly geopolitical impact as they are likely to reduce Russian influence in Western Europe! The EU has meanwhile welcomed such measures, which would intensify transatlantic relations [44, 45].

\section{Asia and energy scarcity}

In Asia, the energy situation has not undergone the radical transformations North America has encountered and consequently this area is still coping with relative energy scarcity [46]. As a consequence, energy as well as resource prices are comparatively high; in the case of natural gas for instance, the Asian price can be almost an order of magnitude higher than in North America, a phenomenon referred to as Asian premium [47]. In order to assess the Asian situation, we will herein assess the most extreme case-Japan. The island nation is resource-poor and has hence based its energy security policy on nuclear power in order to be relatively independent of resource imports (roughly $30 \%$ of its electricity production had stemmed from nuclear power). Unfortunately, Japan is also the most earthquake-prone country in the world and the devastation of a nuclear power plant in Fukushima in 2011 has had a devastating impact on Japan and the perception of nuclear power. After the disaster in Fukushima, the authorities suspended nuclear power production pending a thorough and comprehensive review of reactor security. It is anticipated that some reactors will go online again after being cleared by the authorities; however, it is unlikely that former levels of nuclear power production will be reached in the foreseeable future. The restructuring of the Japanese energy landscape in the aftermath of the Fukushima

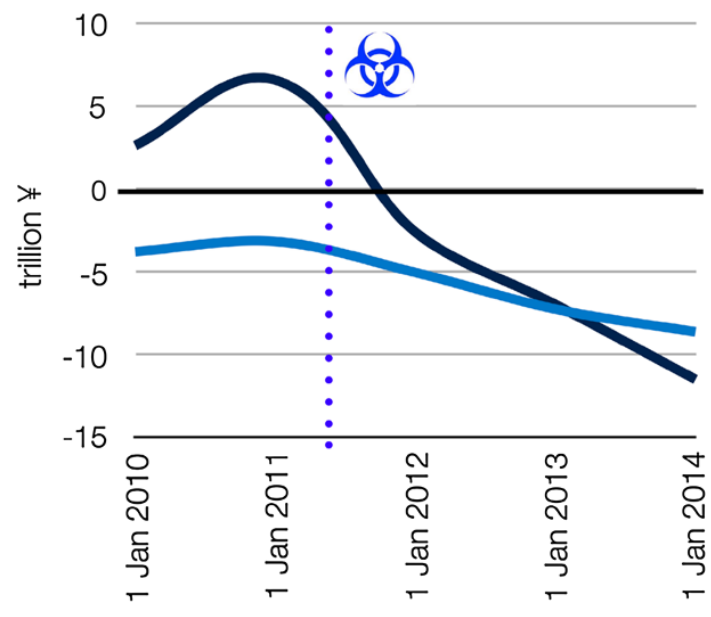

Fig. 6 Natural gas imports and trade balance, data from the OECD [48] and the EIA [49]

disaster was neither straightforward nor cheap. One of the main power (electricity) sources to replace nuclear generation is natural gas, which has to be bought at the mentioned Asian premium prices critically Japan's economic competitiveness. In Fig. 6, cost of natural gas imports into Japan as well as the Japanese trade balance since 2010 are depicted; from this illustration it can be seen that resource imports after the Fukushima accident in March 2011 increased, and hence cash flows abroad. Coupled to these cash flows out of Japan, the trade balance has for the first time in decades shifted into the negative! As in case of the US, the trade deficit directly affects balance of payments, foreign debt and thus Japan's long-term economic outlook.

In addition to this detrimental macroeconomic impact, particularly industries that use natural gas as a feedstock and are also energy-intensive are affected by imports of pricy resources and rising energy prices as costs of two input factors increase in a coupled manner. This additional cost entering production prices in a twofold manner directly affects competitiveness of companies located in Japan compared to companies located in areas with lower feedstock prices, such as those in the United States. Even though Japan does not possess significant amounts of shale gas, it has reasonable amounts of so-called methane hydrates. Methane hydrates also known as frozen methane or methane clathrate is methane trapped within a frozen water crystal and is deposited in significant amounts on the ground of deep waters off the Japanese shores. This unconventional resource could potentially be a game changer for Japan just as shale has changed the North American energy landscape. Figure 7 maps the confirmed, potential and possible methane hydrate reserves off Japan's shores: the Eastern Nankai trough contains confirmed reserves of 500 billion cubic meters and it is estimated that more than a trillion cubic meters, enough to satisfy Japan's natural gas needs for more than a decade. If Japan wants to 


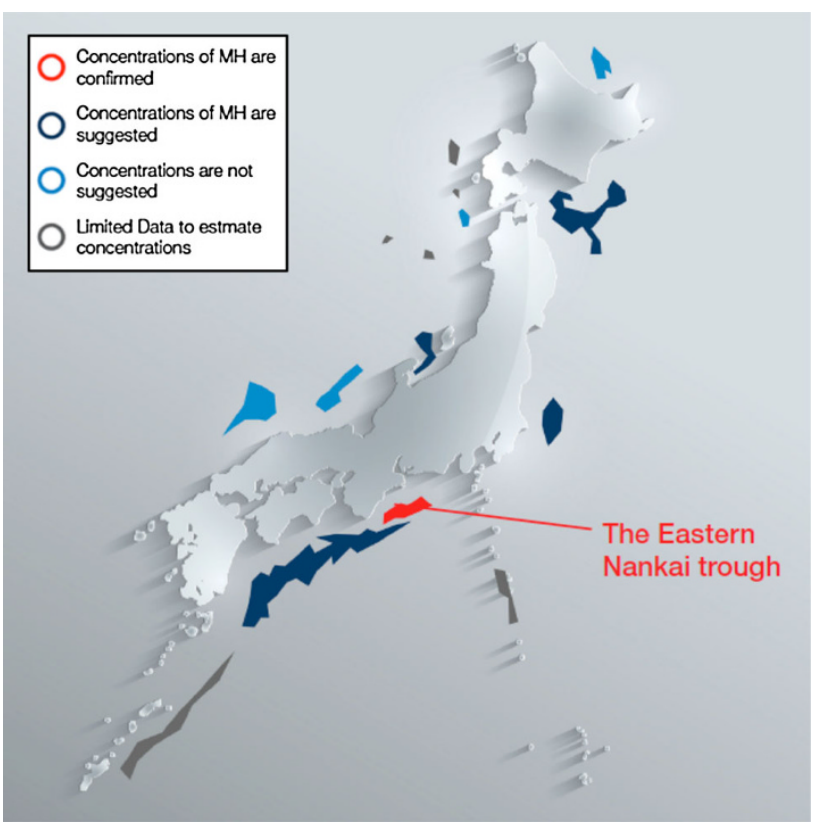

Fig. 7 Confirmed, potential and possible methane hydrate $(\mathrm{MH})$ reserves

transition out of nuclear power, these unconventional gas resources could be the perfect transition fuel. Moreover, it is suggested that the actual reserves are five times as large and could thus have a long-term impact on Japan's energy security and economic outlook [50].

If Japan could utilise this unconventional resource, the macroeconomic implications would be as strong as in the US: the current trade deficit could be shifted back to a trade surplus, competitiveness with other regions of the world could be restored through declining energy and feedstock prices and last but not least, energy security could be increased which would likely mitigate if not resolve tensions with other Asian states-yet another geopolitical impact of the restructuring of the feedstock curve. There are, however, concerns about feasibility of these projects; for instance, Japan's food security is largely based on maritime supply and hence any environmental damage in relation to off-shore production of methane hydrates could directly affect food security. Nevertheless, also here unconventional feedstock and the transformation of the feedstock curve could have significant political and economic implications.

\section{Discussion}

Technological advancements in fossil fuel production have-within a few years-altered the mix of resources we utilize, the so-called feedstock curve. The transformation of the feedstock curve has in turn had a drastic impact on the macroeconomic outlook of, for instance, the United States and could potentially affect other countries, like Japan, in a similar manner. The United States, once the biggest producer of petroleum, became highly dependent on fuel imports, but has undergone an energy transformation and is meanwhile independent of natural gas imports and is likely to become relatively independent of oil imports. Hence, the technological advancements that enabled the production of unconventional resources, have had significant macroeconomic impact as they are likely to reduce the enormous trade deficit of the US and hence will improve the country's macroeconomic outlook. What implications does this have for geopolitics? As an example, the United States is policing the seven global oil chokepoints [51] and provides stability to the Middle East through diplomatic channels and military presence. Will this continue when the US only has to import relatively minor amounts of petroleum which are likely to come from Canada, Mexico and Venezuela? Will they continue to sustain a costly presence in the Middle East when Saudi oil supply is not critical for economic survivals anymore? On first glance this would seem that this would not make sense when most oil is domestically produced or imported from adjacent countries, but the US will still want to keep oil prices at least relatively low and since oil is a globally traded commodity, undisrupted trade will be key to ensure equilibrium prices [52]. Therefore, the US is unlikely to abandon the security arena for oil, but it is debatable if they will continue to be involved in the current manner. Import dependent countries such as China will be expected to contribute their fair share to naval security. These issues have to be carefully as well as holistically dealt by energy analysts.

Russia's renewed imperial ambitions are fuelled by fossil resources: almost a billion dollars is transferred to Russia daily for fossil fuel exports and Putin's confidence is growing with every dollar. Especially Europe is dependent on these exports and Russia is sure to have a tight grip on Europe, the current happenings in Eastern Europe are clear signs of this. Through ample gas production in the US and the potential of EU shale gas production, the West could strike back by intensifying transatlantic bonds and gaining independence of imports from the East. After all Russia is as dependent on foreign currency as we are dependent on fossil fuel imports and when cash flows change directions from East to West, many in Russia will be mighty disappointed. Moreover, the increasing energy independence is providing the US with a confidence boost, coined 'barrels of confidence' by Lee and Lahn [53].

Looking at the issue from the resource-rich countries' point of view is interesting as well: the US shale gas boom has kept gas prices in North America relatively low 


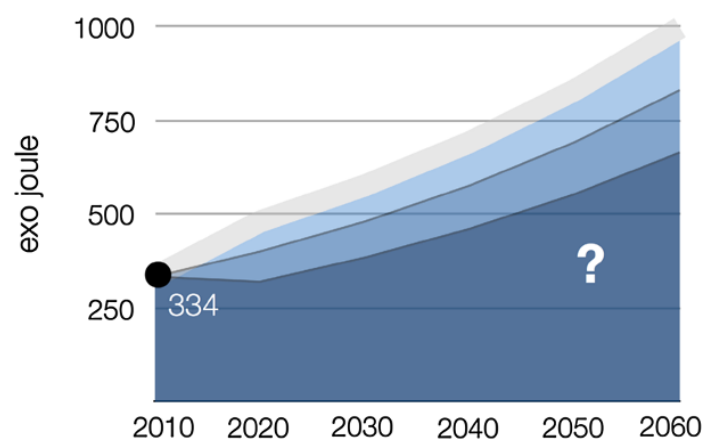

Fig. 8 Global energy demand and uncertainty around the feedstock utilised

compared to Europe and Asia, simultaneously reducing the amount of LNG imports needed. In a similar fashion, tight oil coming online will affect—most likely stabilize—oil prices. For countries relying on resource exports for economic stability, i.e. countries suffering from the resource curse, the shifting feedstock curve should be the final wake-up call: For how long will resource exports manage to finance their political systems? Should the resource wealth be immediately invested in innovation and technology to set these countries on course for a post-resource area? Will unconventional production just be a temporary phenomenon as carbon emission and climate change concerns will impact political agendas so that the resources have to be abandoned? These are critical question governmental strategists have to tackle.

Assessing how things will develop over the coming years is already tricky, but how will all this pan out in the long term? It is tough to forecast how this situation will develop as political, economic and technological issues interact in a highly complex manner. The uncertainty of the three factors listed above is so large that it is hard to predict what will power us in a decade's time. Will unconventionals really crowd out renewable energy or will unconventional gas power the transition to a renewable energy system? Will emerging technologies in battery and grid storage make gas backup for renewables unnecessary? Another tough call to make as technological developments can disrupt complete industries within a few years. Moreover, emerging technologies can-within years-impact the amount of energy we use and hence there is not only significant uncertainty around the resources we will utilise but also the amount of energy we demand to ensure a smooth functioning of the globalised economy. The only thing that is certain is that in 2010 we utilised 334 exo joule of nuclear, fossil and renewable energy (Fig. 8), how energy demand will evolve or which resource will be in demand is highly uncertain. Moreover, will cheap unconventional resources crowd out renewables or high-emissions resource out of the feedstock curve? Also this is highly uncertain and therefore the environmental impact of unconventionals.

Resources have always had a tremendous impact on geopolitics, but resource accessibility by technological advancements has made this mix so volatile that tide turns very quickly and with wide ranging consequences. This is why the feedstock curve has to be monitored closely in collaboration with businesses, public officials and independent researchers to gain a clear view of how it affects international economics as well as geopolitics. Due to multiple, often coupled, uncertainties, predictions only make sense over a few years and consequently have to be continuously reassessed.

\section{Conclusions}

Unconventional resources will continue to restructure the energy landscape as well as the feedstock curve and they will be critical for the recovery of the global economy. Economic and political factors are driving the exploration of unconventional fuel resources which can provide energy security, while financial considerations push technological frontiers in resource production.

The provision of energy security has risen to the top of the political agenda due to renewed geopolitical tensions in Eastern Europe and the far East Asia as well as economic necessity due to large trade deficits of advanced economies which could lead to a long-term instability of the globalized economy.

Production of unconventionals could indeed have a detrimental effect on the environment by increasing greenhouse-gas emissions, impacting water and crowding out investment in renewables. When carefully regulated, impact on water could be minimized while greenhouse gas emissions would be reduced when unconventional gas crowds out coal and provides efficient backup for renewable power. Implementation of smart policies will be critical to ensure that these resources are not only a winner for politics and economics but also for the environment.

Moreover, we have to extend our assessments: at the moment, we carefully forecast energy demand and assess potential resources that could be used to supply this demand. Nevertheless, the ICT revolution has made technological progress both fast and volatile so that we have to use 'intelligence' and assess lab-stage technologies with regards to their potential impact on both energy supply and demand.

Resources and the energy security they provide have often not only impacted the economic success of countries but also the geopolitical balance of power, the renewed power struggle in Eastern Europe is clearly a sign of this trend. It has to be closely monitored how the technological 
redistribution of fossil resources will impact issues such as tensions between Japan and China, the reoccurring conflict in the Middle East as well as the renewed power struggle between East and West.

Collaborative endevours including acedemics, businesses and governmental agencies will be critical for monitioring the feedstock curve and its potential impact on the globalized economy.

Open Access This article is distributed under the terms of the Creative Commons Attribution License which permits any use, distribution, and reproduction in any medium, provided the original author(s) and the source are credited.

\section{References}

1. http://online.wsj.com/news/articles/ SB10001424127887324767004578489130300876450

2. Owen NA, Inderwildi OR, King DA (2010) The status of conventional world oil reserves-hype or cause for concern? Energy Policy 38(8):4743-4749

3. Hall CAS, Lambert JG, Balogh SB (2014) EROI of different fuels and the implications for society. Energy Policy 64:141-152

4. Hall CAS, Klitgaard KA (2012) Energy and the wealth of nations. Springer, Berlin

5. US Governments, Energy Information Administration, Washington D.C., USA

6. US Department of Commerce, US Census Bureau, https://www. census.gov/, Washington D.C., USA

7. US Department of Commerce, US Census Bureau, https://www. census.gov/, Washington D.C., USA

8. http://www.eia.gov/dnav/ng/hist/n9100us2a.htm

9. http://environment.yale.edu/envy/stories/fracking-outpaces-scienceon-its-impact

10. http://www.ft.com/intl/cms/s/0/a5053c50-8d2b-11e1-9798-00144 feab49a.html\#axzz2x4YiJGsh

11. http://www.eia.gov/naturalgas/

12. Speight JG (2010) The refinery of the future. William Andrew, London

13. Hashiguchi BG et al (2014) Science 343(6176):1232-1237

14. Troner A (2013) Natural gas liquids in the shale revolution. Baker Institute, Rive University http://bakerinstitute.org/files/3961/ download/

15. Brantley SL et al (2013) Water resource impacts during unconventional shale gas development: The Pennsylvania experience. Int J Coal Geol. http://dx.doi.org/10.1016/j.coal.2013.12.017

16. International Energy Agency (2013) Are we entering the golden age of shale gas. Paris, France. http://www.worldenergyoutlook. org/media/weowebsite/2011/WEO2011_ GoldenAgeofGasReport.pdf

17. http://www.bbc.co.uk/news/mobile/business-12245633

18. http://www.eia.gov/environment/emissions/carbon/

19. Stevens P (2012) The shale gas revolution. Chatham House http:// www.chathamhouse.org/sites/default/files/public/Research/Energy,\%20Environment\%20and\%20Development/bp0812_stevens. pdf

20. Inderwildi OR, King DA (2012) Energy, transport \& the environment. Springer, Berlin

21. Inderwildi OR, Jenkins SJ, King DA (2008) J Phys Chem C 112(5):1305-1307
22. Inderwildi OR, King DA (2009) Energy Environ Sci 2(4):343-346

23. http://www.bloomberg.com/energy/

24. http://www.eia.gov/dnav/pet/pet_move_impcus_a2_nus_ep00_ im0_mbbl_m.htm

25. Scott RE (2013) http://www.epi.org/publication/trade-deficitsconsequences-policy-implications/

26. http://www.frbsf.org/education/publications/doctor-econ/2007/june/trade-deficit-exchange-rate

27. http://www.reuters.com/article/2011/08/06/us-usa-debt-downgradeidUSTRE7746VF20110806

28. Checherita-Westphal C, Rother P (2012) Eur Econ Rev 56(7): 1392-1405

29. Diplomatic Council on Energy Security http://www.secure energy.org/sites/default/files/DCES-Oil-and-the-Trade-Deficit. pdf

30. International Monetary Fund, World Economic Outlook (2013) http://www.imf.org/external/pubs/ft/weo/2013/01/pdf/text.pdf

31. Friedrichs J, Inderwildi O (2013) The carbon curse: are fuel rich countries doomed to high $\mathrm{CO}_{2}$ intensities? Energy Policy. doi:10. 1016/j.enpol.2013.07.076

32. http://www.iea-etsap.org/web/E-TechDS/PDF/P02-Uncon\%20 oil\&gas-GS-gct.pdf

33. World Economic Forum (2013) Energy harnessing: new solutions for sustainability and growing demand

34. http://www.ibtimes.com/us-shale-gas-boom-attracting-investmentschinese-energy-companies-1126087

35. http://www.theguardian.com/environment/2013/oct/11/francefracking-ban-shale-gas

36. http://www.politico.com/story/2014/03/wh-methane-strategy-nextstep-in-climate-plan-105178.html?hp=r13

37. AEA Technology (2012) Climate impact of potential shale gas production in the EU

38. http://www.eia.gov/analysis/studies/worldshalegas/pdf/fullreport. pdf

39. http://www.nytimes.com/2014/03/24/business/international/ weaning-europe-from-russian-gas.html?_r=0

40. http://www.independent.co.uk/voices/comment/oil-and-gas-couldexplain-putins-costly-attempt-to-control-the-crimea-9193464.html

41. http://www.bloomberg.com/news/2014-03-20/eu-readies-naturalgas-plan-to-cut-reliance-on-russia-in-months.html

42. http://www.naturalgaseurope.com/russia-plans-massive-expan sion-of-nord-stream-pipelines-

43. http://www.ft.com/intl/cms/s/0/e2cf61ba-a489-11e3-b915-00144 feab7de.html\#axzz2x4YiJGsh

44. http://www.ft.com/intl/cms/s/0/e539fc24-b37c-11e3-b891-00144 feabdc0.html\#axzz2x4YiJGsh

45. http://www.ft.com/intl/cms/s/0/67308bb8-97f2-11e3-8c0e-00144 feab7de.html\#axzz2x4YiJGsh

46. World Economic Forum (2013) Japanese Energy Transition., Tokyo Japan, http://www3.weforum.org/docs/IP/2014/CH/Japan_ Energy_Report_2014.pdf

47. Ken Koyama IEEJ (2012) A Japanese perspective on the international energy landscape http://eneken.ieej.or.jp/data/4252.pdf

48. OECD, Paris, France; http://stats.oecd.org/index.aspx?queryid= 166

49. http://www.eia.gov/countries/country-data.cfm?fips=ja

50. http://www.ft.com/intl/cms/s/2/8925cbb4-7157-11e3-8f92-00144 feabdc0.html\#axzz2xlXj751E

51. http://www.eia.gov/countries/regions-topics.cfm?fips=wotc\&trk= p3

52. World Economic Forum (2013) The Japanese energy transitions

53. Lee B, Lahn G (2014) Barrels of confidence. Prospect 